\title{
Epicurean Happiness: A Pig's Life?
}

\author{
Epicuri de grege porcum \\ ("A pig from the sty of Epicurus") \\ -- Horace
}

David Konstan (Brown University)

In this paper, I argue that for Epicurus, the highest form and final end of human happiness arises when the body is free from pain and the soul is free from distress; these, moreover, are what Epicurus denotes as the static pleasures. The static pleasures may be accompanied by pleasant thoughts and sensations: these are what are called the kinetic pleasures. More particularly, the kinetic pleasures of the body are not those of replenishment (as is commonly supposed), but consist rather in unalloyed, but also unnecessary, pleasures such as sweet smells and delicious tastes; correspondingly, the kinetic pleasures of the mind are joy (khara) and good cheer (euphrosunê), which also are in the class of non-necessary pleasures.

In an epistle addressed to his melancholy friend and fellow poet, Albius Tibullus, Horace wrote:

Albius, sincere judge of my Satires, what shall I

Say you're doing in your native country at Pedum?

Writing something to outdo Cassius of Parma's pieces,

Or creeping about silently in healthy woodland,

Thinking of all that belongs to the wise and good?

You were never just a body, lacking in feelings:

The gods gave you beauty, wealth, the art of enjoyment.

What more would a nurse desire for her sweet darling

Than wisdom, the power to express what he feels,

With a generous share of kindness, health and fame,

An elegant mode of life, and no lack of money?

Beset by hopes and anxieties, indignation and fear,

\footnotetext{
${ }^{1}$ I am much indebted to Francesco Verde and Phillip Mitsis for their comments on an earlier draft of this paper.
} 
Journal of Ancient Philosophy Vol. VI 2012 Issue 1

Treat every day that dawns for you as the last.

The hour that's unhoped for will be welcome when it comes.

When you want to smile then visit me: sleek, and fat

I'm a hog, well cared-for, one of Epicurus' herd.

(trans. A.S. Kline 2003-05, slightly modified) ${ }^{2}$

Horace wittily contrasts his own simple contentment with the brooding temperament of Tibullus, and recommends that he rid himself of cares by ceasing to worry about death and living in the moment - not to concern himself with surpassing Cassius as a poet, nor to brood (Horace's word is curantem) about what kind of behavior is worthy (dignum) of a sage or good person. The advice accords well with Epicurus' emphasis on pleasure as the goal of life, and his belief that what most upsets human lives is the fear of death: rid yourself of that, and you will have all the joy of which human nature is capable -and which, Horace seems to imply, is more or less that of a well-fed and pampered pig.

If indeed pleasure is the supreme goal in life, and if pleasure, moreover, is perceived through the senses, then it would seem to follow that a pig, or any other sentient animal, is capable of achieving perfect happiness: hence Horace's image is strictly appropriate for an Epicurean. ${ }^{3}$ In Cicero's treatise $O n$

\footnotetext{
2 Albi, nostrorum sermonum candide iudex, quid nunc te dicam facere in regione Pedana? scribere quod Cassi Parmensis opuscula vincat an tacitum silvas inter reptare salubris curantem quidquid dignum sapiente bonoque est? non tu corpus eras sine pectore: di tibi formam, di tibi divitias dederunt artemque fruendi. quid voveat dulci nutricula maius alumno, qui sapere et fari possit quae sentiat et cui gratia fama valetudo contingat abunde et mundus victus non deficiente crumina? inter spem curamque, timores inter et iras omnem crede diem tibi diluxisse supremum: grata superveniet quae non sperabitur hora. me pinguem et nitidum bene curata cute vises, cum ridere voles, Epicuri de grege porcum.
}

3 On the idealization of the lowly pig by the skeptic Pyrrho, see Warren 2002: 113-16; as Warren observes (11516), "A pig is to be imitated not because it doubts its senses, but because it does not worry about whether a storm is bad." On pigs in connection with Epicureanism, see the learned account in Warren 2002: 129-49; Warren notes (134) that "The Epicurean pig, when used as a positive symbol, recalls only the tranquil state of that animal rather than its psychological incapacities." Warren reproduces (133) a photograph of a bronze pig discovered in the Villa of the Papyri in Herculaneum, which contained the library of the Epicurean philosopher Philodemus. 
Journal of Ancient Philosophy Vol. VI 2012 Issue 1

Ends (De finibus), the Epicurean Torquatus explains the doctrine of pleasure in just such terms (1.11.29):

We are inquiring, then, what is the final and ultimate good [extremum et ultimum bonorum], which as all philosophers are agreed must be of such a nature as to be that to which all other things are referred, while it is not itself referred to anything else. This Epicurus locates in pleasure [voluptas], which he holds to be the highest good [summum bonum], and pain the highest evil [summum malum]. This he sets out to prove as follows: Every animal, as soon as it is born, seeks pleasure and delights in it as the highest good, while it avoids pain as the highest evil and so far as possible avoids it. This it does as long as it remains unperverted, its nature itself judging honestly and uncorrupted. ${ }^{4}$ Hence Epicurus refuses to admit any necessity for argument or discussion to prove that pleasure is desirable and pain to be avoided. These things, he thinks, are perceived by the senses [sentiri], as that fire is hot, snow white, honey sweet, none of which things need be proved by elaborate reasoning: it is enough merely to draw attention [admonere] to them. (trans. based on Harris Rackham, Loeb Library, much modified) ${ }^{5}$

Cicero is a prejudiced source when it comes to Epicurean doctrine, but the account of pleasure that he places in Torquatus' mouth is broadly faithful to Epicurus' own view -- subject to the important proviso that (as we shall see) it is incomplete. ${ }^{6}$ Thus Diogenes of Oenoanda, a confirmed Epicurean who had an entire wall inscribed with the teachings of the school so as to benefit both friend and stranger alike, affirms (fr. 32):

If, gentlemen, the point at issue between these people and us involved inquiry into "what is the means of happiness? [eudaimonia]" and they wanted to say "the virtues [aretai]" (which would actually be true), it would be unnecessary to take any other step than to agree with them about this, without more ado. But since, as I say, the issue is not "what is the means of happiness?" but "what is happiness and what is the ultimate goal [to eskhaton] of our nature?", I say both now and always, shouting out loudly to all Greeks and non-Greeks, that pleasure [hêdonê] is the end [telos] of the best mode of life, while the virtues, which are inopportunely messed about by these

\footnotetext{
${ }^{4}$ Cf. Brunschwig 1986.

${ }^{5}$ quaerimus igitur, quid sit extremum et ultimum bonorum, quod omnium philosophorum sententia tale debet esse, ut ad id omnia referri oporteat, ipsum autem nusquam. hoc Epicurus in voluptate ponit, quod summum bonum esse vult, summumque malum dolorem, idque instituit docere sic: omne animal, simul atque natum sit, voluptatem appetere eaque gaudere ut summo bono, dolorem aspernari ut summum malum et, quantum possit, a se repellere, idque facere nondum depravatum ipsa natura incorrupte atque integre iudicante. itaque negat opus esse ratione neque disputatione, quam ob rem voluptas expetenda, fugiendus dolor sit. sentiri haec putat, ut calere ignem, nivem esse albam, dulce mel. quorum nihil oportere exquisitis rationibus confirmare, tantum satis esse admonere.
}

6 Tsouna 2007: 14 argues that Philodemus was an important source for the account of Epicureanism in the first two books of Cicero's On Ends. 
Journal of Ancient Philosophy Vol. VI 2012 Issue 1

people (being transferred from the place of the means to that of the end), are in no way an end, but the means to the end. (trans. Smith 1993) ${ }^{7}$

Similarly, Diogenes Laertius, who is sympathetic to Epicureanism, reports (137-38) that Epicurus

cites as proof that pleasure is the chief good the fact that all animals from the moment of their birth are delighted with pleasure and distressed by pain by their natural instincts, without need of reason. Therefore also, we, with our own inclinations, flee from pain.... And we choose the virtues too on account of pleasure and not for their own sake, just as we take medicine for the sake of health.... Epicurus describes virtue as inseparable from pleasure, while everything separable from pleasure is expendable.

Finally, Epicurus himself states in his Letter to Menoeceus (128-29): "And so we say that pleasure [hêdonê] is the beginning and end [arkhê kai telos] of living blessedly [tou makariôs zên], for we recognize pleasure as the first and innate good, and on the basis of pleasure we make a beginning for every choice and avoidance, and we arrive at pleasure by judging every good by means of sensation as our measure [hôs kanoni tôi pathei]." 8 What is more, there can be no doubt that Epicurus is referring to corporeal pleasure -- not of the body as such, of course, since the body apart from the soul can perceive nothing at all, but the body in combination with that part of the soul that perceives; as a fragment preserved in Plutarch puts it, "The beginning and the root of all good is the pleasure of the stomach; even wisdom and culture must be referred to this." And another fragment, preserved by Athenaeus (12.546E) and still more notorious, ascribes to Epicurus (in his treatise, On the End or Peri tou telous) the statement: "I cannot think what the good is, if I subtract the pleasures of taste, subtract those of sex,

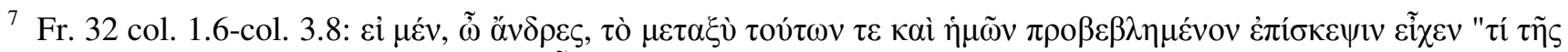

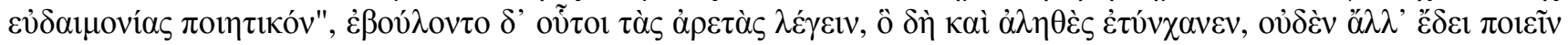

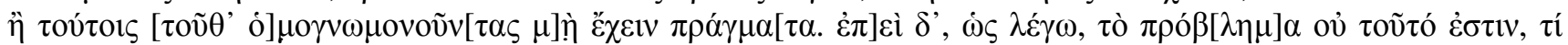

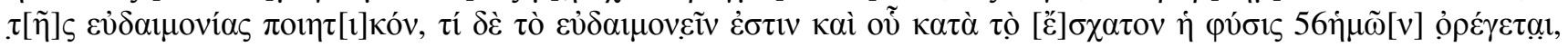

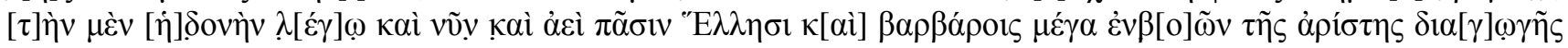

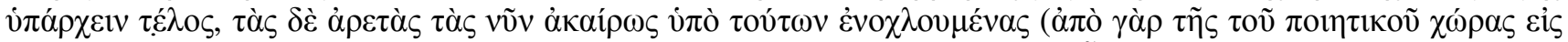

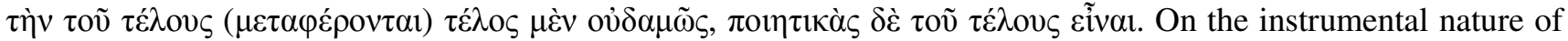
the virtues in Epicureanism, see also Epicurus Letter to Menoeceus 132; Philodemus On Choices and Avoidances (ed. Indelli and Tsouna) XIV 1-14, with Tsouna 2007: 27.

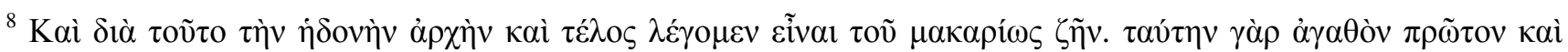

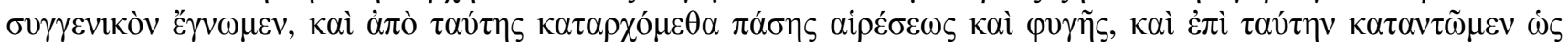

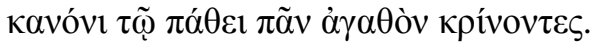


Journal of Ancient Philosophy Vol. VI 2012 Issue 1

subtract those of sounds, and subtract the pleasant motions that arise from the sight of a beautiful form" (cf. Cicero Tusculan Disputations 3.8.42).

If these pleasures are all there is to Epicurean happiness, then it would indeed seem that a pig is capable of enjoying the highest good, provided -- and this is a significant qualification -- that it can do so permanently, something that pigs by and large cannot secure by their own efforts. Still, all that they would lack in this case is continuity of their pleasure, for which they depend on a good herdsman; the nature of their pleasure is not different from that enjoyed by more self-sufficient human beings. ${ }^{9}$

In Plutarch's essay Gryllus, also entitled "On the Fact that Unreasoning Creatures Employ Reason," one of men whom Circe has turned into a pig refuses Odysseus' offer to have him converted back to human form, insisting that a pig's life is superior to that of human beings (Circe has given him temporarily the gift of speech and comprehension). ${ }^{10}$ Much of the pig's argument turns on demonstrating that his species is more virtuous, and hence happier, than humans, and since virtues were generally understood to depend on reason, the pig's claims are plainly paradoxical, like the alternate title of the dialogue itself. In the course of his proof that pigs have great self-control or sôphrosunê, however, Gryllus (as the pig is called) appeals precisely to the Epicurean distinction among desires or appetites as

\footnotetext{
${ }^{9}$ Principal Doctrine 18 states that "Pleasure in the flesh is not increased, when once the pain deriving from lack is eliminated, but merely varied; the limit of the mind in relation to pleasure is provided by the calculation of those

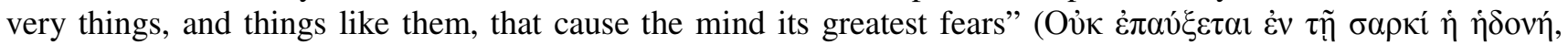

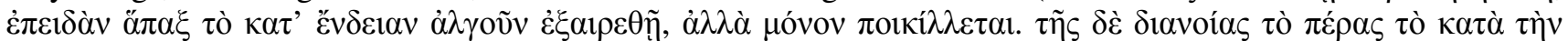

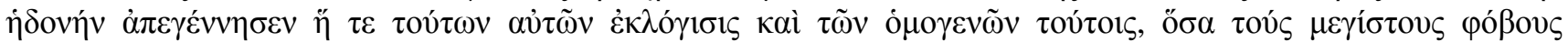

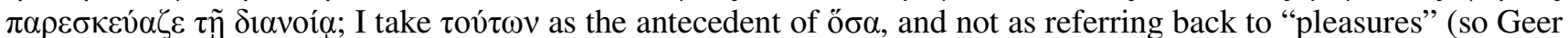
1964: 62; contra Bailey 1926: 99; Inwood and Gerson 1994: 33): the flesh naturally reaches a state of fulfillment, whereas the mind must reflect in order to rid itself of perturbations. Principal Doctrine 20, however, is problematic; I translate: "the flesh takes the limits of pleasure as unlimited, and limitless time provides it [i.e., pleasure], but the mind makes a calculation of the end and limit of the flesh and, dissolving fears concerning

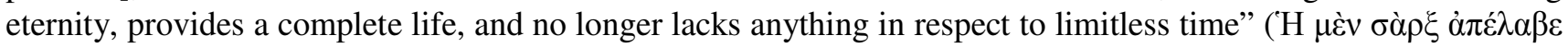

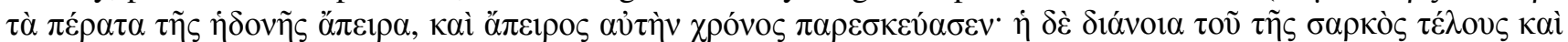

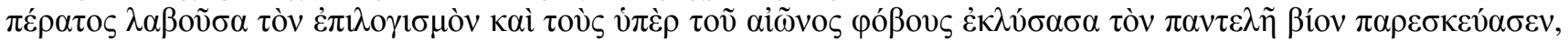

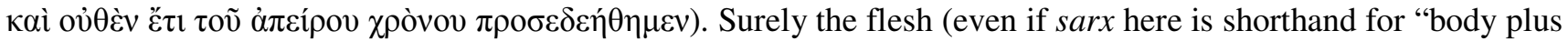
the non-rational part of the soul, which is the seat of perception") does not have beliefs (as Geer 1964: 62 takes it) or make judgments. The idea must be, I think, that the pleasure of physical well-being in and of itself is not marked by a sense of limit, and so is wholly satisfying; the mind, however, is aware of the temporal limits of flesh and so must achieve a sense of its completeness by banishing fears of death.
}

${ }^{10}$ For further discussion of the Gryllus, see Konstan 2011. 
Journal of Ancient Philosophy Vol. VI 2012 Issue 1

(1) natural and necessary, (2) natural but not necessary, and (3) neither necessary nor natural but arising out of empty or false belief (kenê doxê, 989B-C; cf. Epicurus Letter to Menoeceus 127; Principal Doctrine 29). ${ }^{11}$ Human beings, he alleges, are susceptible to the last kind -- we understand that they are capable of having beliefs, and hence false as well as true ones -- whereas "wild animals have souls that are wholly inaccessible to and unmixed with extrinsic passions [pathê] and in their lives are remote from empty belief" (989C). Of course, if animals are by nature immune to unnatural desires and free of empty doxa -- as they are from all belief, whether true or false -- then they have no need of sôphrosunê, the object of which is to govern such appetites. But if Gryllus' position is wittily illogical in regard to virtues, which were central to the good life in Stoicism and other ancient schools, he may still have a case that his is the best life on Epicurus' view, in which the natural pleasures are indeed represented as the highest objective in life. Here again, Epicurean happiness would seem to be something that a pig can lay claim to enjoying.

There is, however, a flaw in Gryllus' position, and this apart from his acknowledged dependency on Circe's tendance of her metamorphosed herds (and hence his insufficiency to secure his own happiness). The Epicurean definition of the highest good is not in fact reducible to the enjoyment of pleasures, however natural. Lucretius, for example, exclaims in the proem to the second book of his poem, De rerum natura, Lucretius:

O minds of mortals, blighted by your blindness! Amid what deep darkness and daunting dangers life's little day is passed! To think that you should fail to see that nature importunately demands [latrare] only that the body may be rid of pain, and that the mind [mens], divorced from anxiety and fear, may enjoy agreeable sensation [iucundus sensus]! (trans. Smith 2001: 35-36, modified) ${ }^{12}$

\footnotetext{
${ }^{11}$ Erroneous beliefs are referred to as hupoleipseis in Letter to Menoeceus 124, in connection with popular conceptions of the gods; these clearly cannot be ascribed to animals. On such "suppositions," see Verde 2010: $126-28$.

12 o miseras hominum mentis, o pectora caeca! qualibus in tenebris vitae quantisque periclis degitur hoc aevi quodcumquest! nonne videre nil aliud sibi naturam latrare nisi utqui corpore seiunctus dolor absit, mente fruatur iucundo sensu cura semota metuque? (2.14-19)
} 
Journal of Ancient Philosophy Vol. VI 2012 Issue 1

What nature -- human nature, presumably, but also the natural order of things -- howls out for is in the first instance an absence, that is, freedom both from physical pain and mental anguish. The word latrare refers literally to the barking of dogs, and Lucretius no doubt employs it here not just to indicate an emphatic appeal, as Martin Ferguson Smith renders it, but the claim of nature at the most basic animal level. A further benefit of the lack of physical and mental misery is the ability to enjoy pleasant sensations. Lucretius faithfully reflects Epicurus' own conception; as he writes in his Letter to Menoeceus (128), just before the passage from this same epistle cited above:

an unerring theory of the desires knows to refer every choice and avoidance to the health of the body and the inperturbability [ataraxia] of the soul, since this is the goal [telos] of living blessedly. We do everything for the sake of this, so that we may neither be in pain [algômen] nor tremble fearfully [tarbômen]. Once this is the case for us, the entire storm of the soul is dissipated; since the animal [to zôon] cannot proceed as though to something it needs and seek something else by which the good of the soul and body will be fulfilled [sumplêrôsetai]. For it is then that we have need of pleasure, when we are in pain because pleasure is not present: when we are not in pain, we no longer need pleasure.

If the goal of life is liberation both from bodily pain and from mental or psychological anxiety, then animals will only be able to enjoy this highest good if they know both kinds of freedom. Now, we have seen that animals are not capable of entertaining false beliefs, inasmuch as they do not have beliefs at all: that is, they are capable of perception, but not reason in the full sense of logos. Epicurus regarded the human soul as having two parts: thus, a scholium that has found its way into the text of Diogenes Laertius $(10.66=$ fr. 311 Usener) reports: "He says elsewhere that it [the soul] is made up of very smooth and round atoms, which differ greatly from those of fire; and one part of it is non-rational [alogon], and dispersed throughout the rest of the body; but the rational part [to logikon] is in the chest [thôrax], as is evident from fears [phoboi] and from joy [khara]." ${ }^{13}$ This account corresponds perfectly to what Lucretius tells us (3.136-51, trans. Long and Sedley 1987 vol. 1: 66-67; Latin words inserted by me):

My next point is that the mind [animus] and the spirit [anima] are firmly interlinked and constitute a single nature, but that the deliberative element [consilium] which we call the mind

\footnotetext{
${ }^{13}$ It may be, as some have argued, that at the time he composed the Letter to Herodotus, Epicurus had not yet thought of the soul as divided, and that the scholium represents a later revision of his view (there is a textual difficulty here as well, involving the reading ti meros, proposed in 1877, vs. the mss. to meros). For full discussion, with bibliography, see Verde 2010: 193-96; also Repici 2008.
} 
Journal of Ancient Philosophy Vol. VI 2012 Issue 1

[animum mentemque] is, as it were, the chief, and holds sway throughout the body. It is firmly located in the central part of the chest. For that is where fear and dread [pavor ac metus] leap up, and where joys [laetitiae] caress us: therefore it is where the mind [mens animusque] is. The remaining part of the spirit [anima], which is distributed throughout the body, obeys the mind [mens] and moves at its beck and call. The mind by itself possesses its own understanding and its own joys [sibi gaudet] while nothing is affecting either the spirit [anima] or the body. And just as, when our head or eye is hurt [laeditur] by an attack of pain [dolor], the agony is not shared [non ... concruciamur] by our whole body, so too the mind [animus] sometimes itself suffers pain [laeditur] or waxes with joy [laetitia] while the rest of the spirit [anima] throughout the limbs and frame is receiving no new stimulus.

The Epicurean Hermarchus is quoted (by Porphyry in his treatise On Abstention from Eating Meat, 1.12) as stating that justice does not obtain between human beings and animals because the animals lack reason or logos (cf. Epicurus Principal Doctrine 32: "For those animals that were unable to form pacts not to harm one another or be harmed, there existed neither justness nor injustice"; Warren 2002: 138-40). Polystratus, in turn, who succeeded Hermarchus as the third head of the Garden (Diogenes Laertius 10.25), denied to animals even the possibility of remembering or anticipating events, including their own past and future states of pleasure and pain (coll. I-VII = Indelli 1978: 109-11; cf. Warren 2002: 137-38). ${ }^{14}$

The Epicurean account of animal consciousness is thus even more reductive, in this sense, than that of other schools, such as the Peripatetic (they were more alike in this respect to the Stoics).

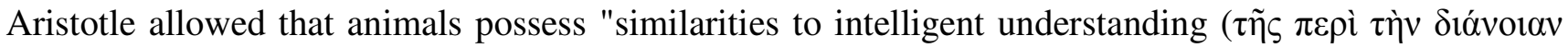

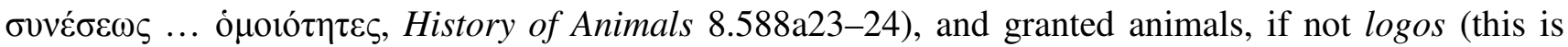
reserved for human beings, Politics 1332b5-6), at least a fairly high degree of practical intelligence or phronêsis, and also (though not quite consistently) memory: "the more intelligent [sunetôtera] ones, which have a share in memory, tend their offspring longer and more sociably [politikôteron]" (History of Animals 8, 589a1-2). At Politics 1253a9-15, however, Aristotle states that "among animals, only the

${ }^{14}$ Principal Doctrine 32 might seem to contradict the proposition that animals are not rational: "Toward those animals that are incapable of making agreements as to not harming one another or being harmed there is neither justice nor injustice, and similarly for those peoples who are either unable or unwilling to make agreements concerning not harming or being harmed." But the argument is, I think, that just as we cannot make agreements with (non-human) animals, so too we cannot make them with certain groups of human beings, and hence there is no relation of justice with them (cf. Bailey 1926: 269). It is not a statement that some non-human animals can enter into agreements. 
Journal of Ancient Philosophy Vol. VI 2012 Issue 1

human being possesses reason. Voicing is a sign of what is painful and pleasant, which is why it pertains

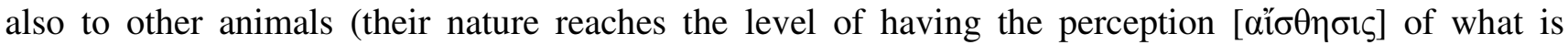
painful and pleasurable and signaling it to one another), but speech [ $\lambda$ ó $\left._{0} \varsigma\right]$ is for manifesting what is advantageous and harmful, and so too what is just and unjust". As a result, only human beings can experience happiness (Parts of Animals 656a5). ${ }^{15}$

A question poses itself: if animals do not have memory or the ability to imagine the future, according to Epicureans, how is it that they experience fear, for example, which would seem to depend on the awareness that certain things, for example predators, can cause them harm? Lucretius provides, I believe, an indication of how it might work, in his explanation -- in materialist terms, to be sure -- of why it is that lions cannot bear the sight of roosters, but instantly take to flight (for this rather odd notion, cf. Pliny Natural History 8.52, Achilles Tatius 2.21, Aelian On the Nature of Animals 3.31):

It is no wonder, since in the body of roosters there are certain constituents, which when they are introduced into the eyes of lions, dig into their pupils and produce a sharp pain [dolor], so that, fierce as they are, they cannot withstand it, although these [constituents] cannot harm our eyes, either because they do not penetrate them or because, though they do penetrate, they are given free passage out of our eyes, so that they cannot harm our eyes in any direction by remaining trapped inside. (4.714-21)

The lion flees roosters because the sight of them produces pain; their simulacra are shaped in such a way as to sting the eyes of lions, though they do not have this effect on human beings. Lions do not believe that roosters pose a threat to them, and so, strictly speaking, they do not fear them, insofar as fear requires an anticipation of a future harm (cf. Aristotle Rhetoric 2.5, 1382a21-25; discussion in Konstan 2006: 129-55). Their behavior does not depend on reason or on memory, and we may suppose that this mechanism applies as well to the natural or instinctive avoidance of harm on the part of animals in general.

Let us return to the matter of pleasure and pain. The Epicureans maintain, according to Diogenes Laertius (10.34), that "there are two experiences [or affections: pathê, plural of pathos], pleasure [hêdonê] and pain [algêdôn], which exist in every animal, the one pertaining to what is one's own

15 On animals and reason in classical thought, see especially Sorabji 1993, who argues that Aristotle and the Stoics ascribed a considerably sophisticated role to perception, which substituted for fully human reason or logos; also Newmyer 2006: 10-47. 
Journal of Ancient Philosophy Vol. VI 2012 Issue 1

[oikeion], the other pertaining to what is foreign [allotrion], by which choices and avoidances are distinguished." In this sense, pleasure is the universal goal of sentient creatures, that is, creatures capable of perception or aisthêsis. However, as we have observed, if for animals it is sufficient for their wellbeing simply to be rid of pain and to enjoy pleasure, for human beings this is not sufficient: we also require a mind free from perturbation. These two conditions, taken together, constitute the basis of human happiness. Each part of the soul, the non-rational or alogon part (in Lucretius' terminology, the anima) and the rational or logikon part, is capable independently of experiencing pain of the kind that specifically affects it.

Let us cite once more Lucretius' words: "The mind by itself possesses its own understanding and its own joys [sibi gaudet] while nothing is affecting either the spirit [anima] or the body. And just as, when our head or eye is hurt [laeditur] by an attack of pain [dolor], the agony is not shared [non ... concruciamur] by our whole body, so too the mind [animus] sometimes itself suffers pain [laeditur] or waxes with joy [laetitia] while the rest of the spirit [anima] throughout the limbs and frame is receiving no new stimulus." The pain of the mind consists in fear and similar psychological perturbations (we shall consider shortly the nature of the opposite or positive state of khara or laetitia). An animal may suffer pain in one part of its body and not another, just like us; but we have a part that animals do not, namely the rational portion of the soul; a pig, for example, can no more feel pain or pleasure in this area of the psyche than human beings can feel pain in their tails, and for the same reason: we do not have tails any more than pigs have a logikon part of their souls.

Still, there is a difference between the two cases: the pain that pigs or we feel in one or another part of our body, and which of course involves the non-rational part of the soul as well (dead bodies feel no pain), is the same in kind, no matter what part is affected: it is called dolor or algêdôn, terms that refer specifically to physical pain. The discomfort of the rational soul, however, is of another kind: it consists in being in a fearful or anxious state (cf. Epicurus' term tarbômen, and Lucretius' cura), and this depends on entertaining certain kinds of beliefs -- false ones, as it happens -- concerning the nature of death and other things we wrongly regard as harmful. Human beings require that both the non-rational and the rational parts of the soul be free of their respective types of trouble. What is more, the perturbations of the mind carry with them severe consequences for human life, in that people, in a vain 
Journal of Ancient Philosophy Vol. VI 2012 Issue 1

attempt to avoid death, which they mistakenly perceive as an evil, are driven to seek unlimited wealth and power, as though these could keep death at bay and thus allay their anxiety. These desires, which go beyond the fulfillment of any and all natural needs, are the cause of the competition and conflict that beset society and make life a hell on earth (for discussion, see Konstan 2008).

It is now time to consider more closely what the pains of the body and the soul are like. We have already cited Epicurus' view that "we have need of pleasure when we are in pain because pleasure is not present: when we are not in pain, we no longer need pleasure." This rather telegraphic statement involves a doctrine concerning the nature of pleasure that invited considerable criticism in antiquity and has been the source of confusion and debate ever since, namely that pleasure, or at least the highest type of pleasure, which Epicurus labeled "static" or "catastematic," consists precisely in the absence of pain and nothing else. ${ }^{16}$ Epicurus also recognized a kinetic or mobile kind of pleasure. Thus, according to Diogenes Laertius $(10.136=$ fr. 2 Usener) Epicurus stated in his book On Choices (Peri haireseôn) that "ataraxy and freedom from trouble [aponia] are catastematic pleasures [hêdonai]; but khara and good

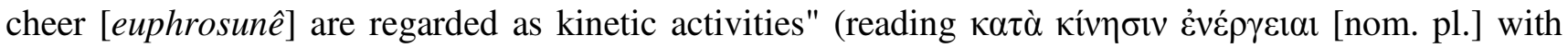

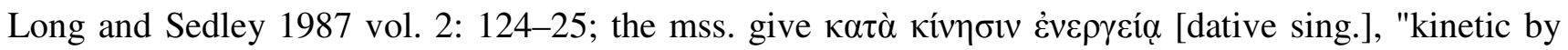
virtue of activity"). ${ }^{17}$

Boris Nikolsky begins his important article on Epicurean pleasure with the words: "Practically every modern survey of the Epicurean conception of pleasure begins by saying that Epicurus' concept of pleasure was twofold: in the opinion of researchers, Epicurus distinguished two kinds of pleasure -- a 'static' pleasure or a pleasure 'in a state of rest' and a 'kinetic' pleasure or a pleasure 'in motion."'18 Unfortunately, most the evidence for the nature of this distinction is late -- Cicero is the chief source --

\footnotetext{
${ }^{16}$ For the background to the idea of an intermediate state between pleasure and pain in Speusippus, Eudoxus, and Aristotle, see Warren 2009.

${ }^{17}$ Wolfsdorf 2009: 223-37 shows convincingly that euphrosunê might naturally be applied to the good cheer arising from bodily pleasures, and that it was so intended by Epicurus; on khara, see Ramelli and Konstan 2010 (Maso 2008: 220 mistakenly takes khara to represent corporeal kinetic pleasure, and euphrosunê that of the mind). Purinton 1991: 287 denies that khara is a pleasure of any kind, and understands it rather as "the intentional state which has pleasure as its intentional object". I am not persuaded that Epicurus took account of such intentional states.
}

${ }^{18}$ Nikolsky 2001: 440. 
Journal of Ancient Philosophy Vol. VI 2012 Issue 1

and not entirely perspicuous. Thus, Torquatus, in the dialogue On Ends (1.37), explains that mobile pleasure "moves our nature by a kind of gentleness and is perceived by the senses with a kind of pleasantness (suavitate aliqua naturam ipsam movet et iucunditate quadam percipitur sensibus), whereas static pleasure "is perceived when all pain is removed" (percipitur omni dolore detracto). As Nikolsky remarks (p. 441): "Here Torquatus draws a distinction between two different states to either of which, in his opinion, the notion of pleasure can be applied -- firstly, a state presupposing active stimulation of pleasant sensations and, secondly, a state negatively defined as the absence of pain and suffering." Cicero further explains, in his response to Torquatus, that "when thirst is quenched it produces a stability of pleasure, he claims, but the pleasure, in turn, of the quenching itself is in motion" (On Ends 2.9: restincta sitis stabilitatem voluptatis habet, inquit, illa autem voluptas ipsius restinctionis in motu est).

Some scholars, including Nikolsky, have sought to impugn Cicero's testimony, pointing to inconsistencies in Cicero's own statements and between his affirmations and other, independent evidence. ${ }^{19}$ These scholars have sought to show that the two ostensibly different kinds of pleasure are in fact one and the same, or at all events that the distinction, such as it is, does not entail the view, which Cicero was pleased to ridicule, that pleasure resides simply in the absence of pain; as Cicero puts it (On Ends 2.6): "either Epicurus, or else all other human beings anywhere in the world, do not know what pleasure is..., since everyone knows that pleasure is that which perception receives and is moved by and is then suffused with a kind of pleasantness" (aut Epicurus, quid sit voluptas, aut omnes mortales, qui ubicumque sunt, nesciunt ... quia voluptatem hanc esse sentiunt omnes, quam sensus accipiens movetur et iucunditate quadam perfunditur). ${ }^{20}$

${ }^{19}$ Cf. Gosling and Taylor 1982: 365-396; also Cooper 1998: 512, who argues that the distinction between static and kinetic pleasures depends on the objects, and is not "a distinction of kind" between the two types of pleasure; for a critique of Nikolsky and of Gosling and Taylor on this score, see Wolfsdorf 2009: 243-53. See also Erler and Schofield 1999: 655, who argue that Cicero's testimony concerning the quenching of thirst (On Ends 2.9, quoted above) "is an isolated text whose interpretation is fiercely contested. It is not easy to reconcile with other evidence, including the explanation of kinetic pleasure as variation Cicero goes on at once to give"; Erler and Schofield suggest that "Perhaps Epicurus himself never indicated how he would classify pleasures of restoration of the body's natural state."

${ }^{20}$ As Francesco Verde reminds me, Cicero's statement may be evidence of an evolution of the Epicurean doctrine of pleasure by his time. 


\section{Journal of Ancient Philosophy Vol. VI 2012 Issue 1}

There is, however, sufficient testimony that, for Epicurus, static pleasure consists in the absence of pain or perturbation, whether in the body or the mind; as Epicurus puts it (Principal Doctrine 3), "The limit of the magnitude of pleasures is the removal of all that causes pain, and wherever there is pleasure, for as long as it is there, there does not exist that which causes pain or distress or the two combined." Far from regarding the idea is incoherent or absurd, I believe that it reflects an important aspect of Epicurus' philosophy, namely that human beings (and indeed animals too, in their more limited way) are naturally in a state of pleasure when they are healthy and free of cares; our natures are thus perfectly suited to attaining the goal of pleasure, by the simple means of eliminating the sources of pain. This is not, of course, always easy or possible, but given that our physical needs are, according to Epicurus, relatively limited, and that most of the psychological perturbations that afflict us depend on empty or erroneous beliefs and can be eradicated entirely (there do exist rational fears, of course, and while these can be managed they are potential sources of distress), human beings are well adapted to achieving what for Epicurus is the goal of life.

How, then, does Epicurus understand the pleasure that consists in the mere absence of pain or perturbation, and what has this to do with the distinction between static and mobile pleasures? When I wrote my book on Epicurean psychology (most recent edition published in 2008), I held the conventional view, criticized by Cicero but plausible on the surface, that "kinetic pleasures are those associated with fulfilling any kind of need, and above all a natural one like eating" (Konstan 2008: $14 \mathrm{n}$. 19). Thus, static pleasure consists in the satiated state of the body when one has finished eating, that is, when one has supplied the deficiency that is perceived as the painful sensation of hunger, whereas the process of eating -- clearly a kind of activity or motion -- is the source of kinetic pleasure. ${ }^{21}$ I have come

\footnotetext{
${ }^{21}$ The view, that is, of Cicero's Epicurean spokesman Torquatus in On Ends 2.9-10, cited above. Cf. Rosenbaum 1990: 24: "The difference between kinetic and katastematic pleasure seems to be that between the pleasure of the activity of satisfying desires, wants, or urges, and the pleasure of being in a state of having satisfied one's desires, or perhaps as appropriately, being in a state of not having (certain types of) desires or urges"; Held 2007: 18: "Kinetische Lust ist ein Prozess der Schmerzaufhebung, der durch die Zufuhr von Lust Mangel beseitigt und ist damit graduierbar und quantifizierbar." Held argues $(32-33,53)$ that kinetic and static pleasures must be different in kind, since static pleasure is the state (Zustand) that is reached when the process of eliminating pain comes to an end (contrast Hossenfelder 2006: 72, who affirms "dass es nur eine Lust und nicht mehrere Arten gibt"). O'Keefe 2010: 119-20 offers two sources of kinetic pleasure (I agree with the first of these): "'Kinetic' pleasures, as the name suggests, involve movement. Bodily kinetic pleasures are associated with some sort of active titillation of the senses, for example the savoury, greasy taste of a sausage slathered with mustard as it caresses
} 
Journal of Ancient Philosophy Vol. VI 2012 Issue 1

now to believe that this account is wrong, while at the same time I hold that there is in fact a distinction between static and mobile pleasure in Epicurean doctrine. The incorrect interpretation, to which I was party, has its origin, as Nikolsky shows in the above-cited article, in the traditional view of pleasure and pain, which was analyzed most penetratingly by Plato and became the basis of the Cyrenaic theory of pleasure, which Epicurus rejected. On this view, as Plato noted, pain and pleasure are not strictly speaking opposites: for pain consists in a lack, whereas pleasure consists in the filling of the lack. Pain is thus a state, whereas pleasure is a process, and ordinary language is wrong in regarding them as contraries. What is more, Plato observed that, so understood, pain and pleasure necessarily co-exist, since one must be at least partially hungry -- in a state of lack -- to enjoy the process of replenishment. Plato regarded such pleasure, accordingly, as impure or mixed. Such were the difficulties that beset the conventional view, as Plato saw it, at all events when he was writing the Gorgias: thus, at 496C-E, peinê and dipsê are described as aniaron or painful, whereas eating and drinking are a plêrôsis or filling and hence pleasurable. $^{22}$

The Cyrenaics, who were followers of Aristippus, a disciple of Socrates, evidently adopted Plato's view of pleasure wholesale. Pleasure, they maintained, consists precisely in restocking the depleted resources of the body, which is far more capable of enjoyment than the mind; hence, one should cultivate desires with the purpose of satisfying them and thus experiencing the greatest quantity of pleasure possible (Diogenes Laertius 2.86-90, where the Cyrenaic view that all pleasure is kinetic is contrasted with the Epicurean conception). Epicurus, however, took a different line: he affirmed that pleasure really is the opposite of pain, and that inasmuch as pain resides in a deficiency or lack, pleasure

my tongue. They also seem to be associated with the process of satisfying some desire. For example, I am hungry, and this hunger is painful. But then, as I chew the sausage and swallow it, I am in the process of satisfying my desire for food and replenishing myself, and this process would be a bodily kinetic pleasure." So too Morel 2009: 196 describes "les plaisirs 'en mouvement' ou 'cinétiques,' comme le plaisir de boire quand on a soif, ou encore la joie ou la gaieté qui succèdent aux moments de craintes ou l'angoisses," and he speaks also of "un plaisir de soulagement, de réplétion ou de compensation - ce qu'est le plaisir cinétique." Morel's suggestion that the kinetic pleasures of the mind consist in the process of alleviating anxiety is interesting; however, I offer a different explanation of khara below. On pleasures of replenishment, see also Long and Sedley 1987 vol. 1: 123; contra Wolfsdorf 2009: 249.

${ }^{22}$ Plato may have modified this view in the Philebus, where he identified what is painful rather as a dissolution (lusis) or corruption (phthora), as opposed to pleasure, which is a filling up (31E-32A); here, then, pain and pleasure are both processes, and hence contraries. 
Journal of Ancient Philosophy Vol. VI 2012 Issue 1

consists in a state of sufficiency: both are in this sense static, and neither is a process. What, then, of the pleasure associated with eating, drinking, and the like, which is experienced before the hunger or thirst is satiated? The answer, I now believe, is that this pleasure derives from the partially replenished state of the organ in question. If we suppose, for a moment, that hunger is caused by an emptiness of the stomach, then when one has eaten some food, albeit not enough to fill the void, the stomach is in part full, in part empty: the part that is full, and hence not in need, is the source of the pleasure that consists in stable well-being, while the part that is still vacant is the cause of pain. The two pathê are indeed experienced simultaneously, and in this sense the pleasure is not pure or uniform, but is accompanied by pain. As Lucretius, in the passage quoted above, says, "when our head or eye is hurt by an attack of pain, the agony is not shared [non ... concruciamur] by our whole body," or, more literally, "we are not racked with pain in our whole body," which presumably experiences the pleasure consisting in the stable or healthy state that is not affected by pain; so too, when a particular organ is partly in pain due to a deficiency, the rest of it is not lacking and so enjoys what Epicurus labeled catastematic pleasure. As one satisfies the need, moreover, the pleasure increases until the source of pain has been entirely eliminated and the part affected is wholly sound. The pleasure does not dwindle to zero over the course of this process, but steadily increases until all pain is absent. ${ }^{23}$ It is true that, in the Letter to Menoeceus (131), Epicurus notes that "bread and water render the highest pleasure, when one who is in need [endeôn] is offered them." But Epicurus' point here is not that the pleasure increases with the need, but that the simplest and most available foods can provide as much pleasure as the most elaborate and expensive; of course, there is no gain in pleasure from eating if one is already full. ${ }^{24}$ In these activities, then, there is no place for kinetic pleasure.

\footnotetext{
${ }^{23}$ For a detailed and, to my mind, convincing defense of the view that "Epicurus does not recognize restorative pleasures" (p. 252), see Wolfsdorf 2009; Wolfsdorf connects the Epicurean view with Aristotle's notion of "secondary actuality" (p. 257).

${ }^{24}$ This is not to say that Epicurus was hostile to luxurious pleasures as such; he opposed them only insofar as they are taken to be necessary for happiness. See Woolf 2009 for the argument that, according to Epicurus, "equipped with the belief that little will always suffice, we should indeed choose plenty where available" (p. 162). To the passages cited by Woolf, we may add Lucretius 2.20-36, which affirms that nature does not require elaborate entertainments, but does not reject them per se, except insofar as the effort to acquire the resources needed to supply them drives people to strive for wealth and power. Giannantoni 1984: 44 argues that kinetic pleasure is the "soddisfazione di desideri naturali ma non necessari," whereas kinetic pleasure is derives from the satisfaction of
} 
Journal of Ancient Philosophy Vol. VI 2012 Issue 1

What, then, is the nature of this latter, mobile kind of pleasure? This, I believe, is the "agreeable sensation [iucundus sensus]" that we are free to enjoy, as Lucretius put it, when the body is liberated from pain and the mind from anxious fears. ${ }^{25}$ This pleasure is over and above that which consists in the healthy state of body and mind represented by the absence of pain and perturbation; it involves such unnecessary but harmless pleasures such as the enjoyment of pleasant odors, tastes or sounds, for instance music. These pleasures have no corresponding lack: they are pure surplus, but not for that reason problematic. Still, they are lesser pleasures, which we can take or leave without reducing the state of perfect contentment that derives from the well-being of body and mind. It is these pleasures that Epicurus refers to, I believe, when he declares that when we have achieved a state of pleasure it cannot be increased but only varied: "Pleasure in the flesh is not increased, when once the pain deriving from the lack is eliminated, but it is only varied" (Principal Doctrine 18, cited more fully above).

If the kinetic pleasures of the body consist in such unalloyed, but also unnecessary, things as sweet smells and delicious tastes, what of the kinetic pleasures of the mind? Here, as we have seen, we are fortunate to have a clear statement, in the form of a quotation from Epicurus' On Choices: "ataraxy and freedom from trouble [aponia] are catastematic pleasures [hêdonai]; but khara and good cheer [euphrosunê] are regarded as kinetic activities." Khara, then, or joy (laetitia in Lucretius), which was one of the signs that the mind is located in the chest and hence must itself be an attribute of the rational part of the soul, differs from the mere exemption from fears, which is the natural and positive condition. If it is to be analogous to the unmixed pleasures (in Plato's phrase) that are found in pleasant sights and sounds and the like, then it is presumably a non-necessary pleasure, the absence of which is not associated with pain (or, to put it differently, it does not arise when some associated pain or distress is removed). Since this joy is also the positive counterpart, we are told, of fear, it presumably also depends on belief, or at least on memory and anticipation, and also on calculation and whatever other mental activities exceed mere perception. This is just what we should expect of a function of the logikon part of the soul. I venture to suggest that reflection on past or future goods is among the things that cause this

natural and necessary desires; cf. also Diano 1974: 170, who argues that static pleasure is produced when atoms return to their original (stable) position. For a survey of modern views on the question, see Prost 2004: 119-24.

${ }^{25}$ Cf. Cicero On Ends 2.6-7, which appears inconsistent with his statement that mobile pleasure resides in replenishment; see too Nikolsky p. 441, and O'Keefe 2010: 119-20, cited above. 


\section{Journal of Ancient Philosophy Vol. VI 2012 Issue 1}

kind of joy, as well as any other thoughts that are delightful and are not anticipations of the fulfillment of irrational (as opposed to non-rational) desires -- that is, desires that depend on empty opinion and are themselves a product of empty fears. ${ }^{26}$ Doubtless, the satisfactions of friendship, which was celebrated by the Epicureans, were an important source of such joy, among other reasons because friendship helps instill a sense of security against dangers that might threaten one's tranquility. ${ }^{27}$ As Epicurus puts it (Principal Doctrine 34): "we have use not so much for usefulness in our friends as for confidence in their usefulness."

There remains one further question on the nature of Epicurean pleasure: when we are experiencing the kinetic joy of the mind, is there also associated with it the physical pleasure of hêdonê that is experienced or perceived by the anima or non-rational part of the soul? And does the static enjoyment of ataraxy, when the mind is free from fear and anxiety, entail a kind of sensible pleasure as well? This is what Epicurus evidently says, when he affirms that "ataraxy and freedom from trouble are catastematic hêdonai." My guess is that we do best to take him at his word, and suppose that positive mental states, consisting in the absence of perturbation and the joy residing in pleasant thoughts, are also perceived as pleasures by the alogon part of the soul, which is the locus of aisthêsis or perception. No Epicurean ever claims that the atoms that constitute the non-rational part of the soul are excluded from that part of the chest in which the finer atoms constituting the rational part or animus are located, and it is entirely plausible that the animus intersects or overlaps with the anima. Although Lucretius makes it clear that not every distress or pain experienced in the mind or body necessarily entails a corresponding discomfort in the other part, he goes on to say that when the injury is great, then indeed there is such a consequential effect (Lucretius 3.152-60), since the mind and body are alike material and contiguous. I assume, then, that the pleasure deriving from ataraxy is genuine hêdonê, a pathos experienced in the alogon part of the soul.

${ }^{26}$ Giovacchini 2008: 70 suggests that the pleasure deriving from an awareness of one's own security while observing the dangers to which others are exposed, as described by Lucretius in the proem to Book 2 , is an instance of khara; for the nature of this pleasure, see Konstan 2008: 29-35.

${ }^{27}$ The knowledge that we have friends would thus be the source of kinetic, not catastematic pleasure; contra Wheeler 2003: 184: "friendship -- while not strictly identical with happiness or the greatest good -- is identical with a kind of katastematic pleasure." Of course, insofar as having friends induces a sense of security and hence freedom from fear, it contributes to static pleasure, but is not identical to it. 
Journal of Ancient Philosophy Vol. VI 2012 Issue 1

The combination of the pleasure deriving from a body free from pain and that of a soul free from distress, accompanied, it may be, by pleasant thoughts and sensations, constitutes the highest form and final end of human happiness. With it, we are equal to the gods: duration adds nothing to it, and the subsidiary kinetic pleasures do no more than work variations on the fundamental felicity of well-being. It is not a "neutral" state, as the opponents of Epicurus maintained, between pain and pleasure; it is the state in which all is working as it should, and the opposite of disrupted or distressed conditions of mind or body. ${ }^{28}$ It is not incompatible with a wide range of rational activities that differ from the simple pleasures, for example goal-oriented pursuits that enable us to procure the basic necessities of life or meet some other reasonable need or want; but such projects are not typically where pleasure is to be found. An exception is philosophy. Epicurus writes (Vatican Saying 27): "In the case of other activities their fruit [karpos] is accomplished with hardship, but with philosophy delight [to terpnon] runs hand in hand with knowledge [gnôsis]; for the benefit [apolausis] comes not after learning, but learning and

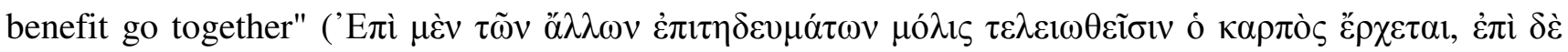

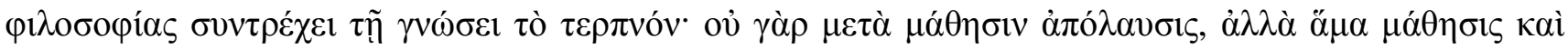
$\dot{\alpha} \pi \mathbf{x}^{\prime} \alpha v \sigma 1 \varsigma$ ). Epicurus is not claiming here (as I mistakenly supposed in my book, p. 16 n. 24) that there are activities in which the pleasure resides in the achievement of a self-defined goal, rather than in the activity itself (philosophy being the exception); he is affirming rather that among the activities that we engage in for the sake of some benefit, philosophy is enjoyable even as we pursue the advantage we seek to obtain from it. I suppose that practicing the violin is also fun (or can be), even as one seeks to become proficient and achieve the benefit of being able to entertain others as well as one self with lovely music. But it is important to note that Epicurus does not locate happiness in the achievement of personal goals; hence a short life in which we may not succeed in realizing all our projects does not diminish human happiness, in Epicurus' view. ${ }^{29}$

\footnotetext{
${ }^{28}$ There is a certain resemblance between Epicurus' view of the pleasure associated with the proper functioning or

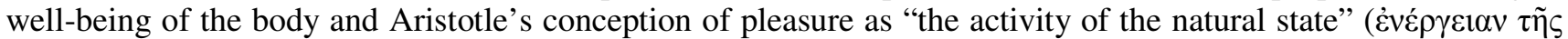

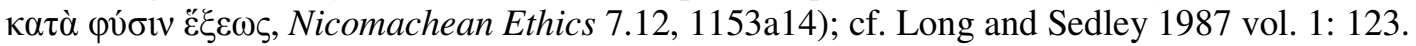

${ }^{29}$ A number of modern scholars have faulted Epicurus for not taking such life projects into account; cf. in particular Nussbaum 1994: 204-22, Rosenbaum 1990, and Striker 1988, in response to Mitsis 1988; see also Mitsis 1996: 811-12: "if we think that death is robbing us of our future possibilities, we need to be careful not to simply appropriate for ourselves possibilities that are not really ours. For the Epicurean, our possibilities end
} 
Journal of Ancient Philosophy Vol. VI 2012 Issue 1

In a way, this is all there is to say about Epicurean eudaimonia. All the rest of the teaching is designed to help people rid themselves of the irrational fears and attendant desires that assail the mind and are the cause of constant struggles for wealth and power that put even the elementary necessities of life at risk. Thus, the elaborate atomic theory inherited from Democritus and further developed by the school is intended to show that survival of the soul, or consciousness in any form after death, is impossible, and hence that the fear of suffering in the afterlife is ungrounded. Freeing the mind from such beliefs is not easy, because they have taken root as human society evolved for reasons that the Epicureans set forth as well. They thus worked out techniques for overcoming such inherited prejudices and fears, including collective study and mutual support in small groups or communities, pedagogical strategies (as outlined in the tract On Frank Speech by Philodemus), and memorization of useful precepts (hence the collection of Principal Doctrines, for example). But the ultimate aim of these methods and tenets was always to help people realize the crucial importance of bodily comfort and above all peace of mind as the be-all and end-all of human happiness, which can be achieved far more safely and with infinitely less peril and expenditure of energy than the things people typically strive for in ignorance of what their natures require.

Unlike other classical philosophical schools, such as that of Plato, Aristotle, and the Stoics, for the Epicureans happiness or bliss (makariotês) and a life worthy of the gods was not by its nature something that only a very few enlightened souls could be expected to achieve. Epicurean eudaimonia was in principle available to anyone: it was a matter of obtaining a basic level of prosperity, which human social organization and technology have made possible for everyone (provided there is no civil strife and a vastly unequal distribution of wealth), and shedding received opinions that were little plausible in themselves (e.g., divine punishment in the afterlife). Of course, such ideas were acquired in childhood, when they could take root and become habitual; still, happiness was not a matter of acquiring transcendental wisdom but simply the state of mental and physical well-being that is the natural condition of human beings. Epicurean philosophy differs in this regard also from the right to the "pursuit of happiness" enshrined in the United States Declaration of Independence: happiness is not pursued, it is

when we go out of existence." For the apparently more nuanced position of Philodemus regarding death, see Armstrong 2004: 32-36, with substantial bibliography. 
Journal of Ancient Philosophy Vol. VI 2012 Issue 1

there for the taking, once one sees what it consists in and provided that one can satisfy the basic needs of the body (Epicurus sometimes speaks as though mental tranquility can override even the most severe pain, and affirms that the sage can be happy on the rack [Diogenes Laertius $10.118=$ fr. 601 Usener], but I take this to be something of a polemical exaggeration, designed to emphasize the fact that the causes of human unhappiness are principally psychological rather than physical, at least among the classes to which the Epicureans addressed their writings). ${ }^{30}$

Epicurus' philosophy, moreover, is a kind of therapy, and is addressed principally to individuals, in the hope of correcting their mistaken ideas and thereby curing them of their personal, even if unacknowledged, disquiet. ${ }^{31}$ Correspondingly, the Epicureans had little interest in seeking political remedies for human misery; they recommended that people avoid engaging in politics, if possible, since it is an arena guaranteed to cause distress. ${ }^{32}$ Epicureans were prepared to offer advice to kings and other sovereigns, such as Roman governors and emperors, who dominated the world in which they lived, though individual cities had their own institutions that typically took the form of a limited democracy managed by and for the local aristocracy. They most certainly preferred to live under good monarchs rather than tyrants, who put their private interest above the welfare of their subjects (see, for example, Philodemus On the Good King according to Homer, addressed to Piso, the father-in-law of Julius Caesar, who was consul in $58 \mathrm{BC}$; Epicurus wrote a treatise, now lost, On Kingship). ${ }^{33}$ One will not find, however, among the writings of Epicurus the kind of utopian republics imagined by Plato or by Zeno and Chrysippus, or the model constitution envisaged by Aristotle in his Politics.

\footnotetext{
${ }^{30}$ Epicurus differed from the Cyrenaics also in holding that mental anguish was worse than physical pain (Diogenes Laertius 10.137), and perhaps went overboard in maintaining that a sage could achieve perfect contentment even in the presence of intense physical discomfort. To this end, Epicurus also argued that physical pains, when intense, are generally brief, and when lasting, moderate enough to be borne with tranquility.

${ }^{31}$ On the medical image of philosophy as therapy, see Salem 1989: 9-21.

${ }^{32}$ For the vicissitudes of the Epicurean advice to "live unnoticed," see Roskam 2007a; also Roskam 2007b. Roskam argues that Epicurus' aphorism was not intended as a blanket prohibition on any and all kinds of political activity, though it later came to be perceived as such.

${ }^{33}$ For a good discussion of the political context and purpose of Philodemus' treatise, see Gigante 1995; see further De Sanctis 2008. Gigante and Dorandi 1980 argue that Epicurus knew the treatise on kingship by Anaxarchus (a companion of Alexander the Great) and shared Anaxarchus' approval of kingship as opposed to tyranny.
} 


\section{Journal of Ancient Philosophy Vol. VI 2012 Issue 1}

Nor did the Epicureans interest themselves, so far as one can tell, in collecting information about the "quality of life" of their contemporaries in the modern sense of the term. Some years ago, I participated in a course called "The Quality of Life," which was taught jointly by members of four different disciplines at Brown University: Philosophy, Economics (alternating with Sociology), Public Health, and Classics (my own department). When introducing my own segment, I observed that what today is called "quality of life" would in classical antiquity have gone under the name of "the good life." The change in terminology is significant. "Quality of life" suggests something that can be measured and evaluated objectively; it evokes international initiatives to invest in the improvement of the lives of people who are impoverished and lack the resources, both material and organizational, to make progress. To be sure, "quality of life," as employed, for example, by Martha Nussbaum and Amartya Sen in their co-edited volume, The Quality of Life (1993), differs from narrowly economic gauges of well-being such as income levels, which fail to take into account the absence of basic necessities such as schools or access to clean water, while at the same time they tend to overlook less material assets that may enhance life considerably, even in the absence of strictly financial prosperity. But such metrics of the quality of life, even if they include intangible elements, do not typically offer theories of happiness such as that of Epicurus and of other classical philosophers. In this respect, the Epicurean approach to eudaimonia may seem irrelevant to modern pragmatic projects to ameliorate the condition of mankind in general.

But Epicurus' conception of eudaimonia may nevertheless be useful to modern debates over happiness for the way it unites, in a materialist view of nature, physical and mental well-being, and understands happiness not as elation or even self-satisfaction, despite the focus on pleasure, but as the normal or healthy human condition. Once one has eliminated the pains and perturbations that afflict both body and mind, there is nothing left to strive for, though there is abundant joy, and this irrespective of duration. Pleasure is a state: it is not a hedonic ideal that aims at maximizing pleasure quantitatively, or a utilitarian calculus like Jeremy Bentham's "sum of pleasures and pains," even though the Epicureans were entirely in favor of sacrificing short-term pleasures at times for the sake of the longer term. Thus, Epicurus writes in the Letter to Menoeceus (129): "every pleasure is a good because of the nature it has, but not every one is to be chosen, just as every pain is an evil, but not every pain is of such a nature as to be avoided." But he does not offer this strategy as a way of measuring contentment, but simply as a 
Journal of Ancient Philosophy Vol. VI 2012 Issue 1

means of securing the well-being of body and mind. Finally, Epicurean eudaimonia is not reducible to positive thinking, or a question of attitude: it is not subjective in this sense. The idea that we simply are happy when we are not beset by pain and above all by anxiety (that is, groundless fears) might inject a dimension that is, I think, relatively rare in modern accounts. ${ }^{34}$

Bibliography

Armstrong, David. 2004. "All Things to All Men: Philodemus' Model of Therapy and the Audience of De morte." In John T. Fitzgerald, Dirk Obbink, and Glenn S. Holland, eds., Philodemus and the New Testament World (Leiden: E.J. Brill, 2004), pp. 15-54.

Bailey, Cyril, ed. 1926. Epicurus: The Extant Remains. Oxford: Clarendon Press.

Bok, Sessela. 2010. Exploring Happpiness: From Aristotle to Brain Science. New Haven: Yale University Press.

Brunschwig, Jacques. 1986. "The Cradle Argument in Epicureanism and Stoicism." In Malcolm Schofield and Gisela Striker, eds., The Norms of Nature (Cambridge: Cambridge University Press, 1986), pp. 113-44.

Cooper, John M. 1998. "Pleasure and Desire in Epicurus." In John M. Cooper, Reason and Emotion (Princeton, NJ: Princeton University Press), pp. 485-514.

De Sanctis, Dino. 2008. "Il buon re di Filodemo tra Epicuro e Omero." Cronache Hercolanesi 38: 165 -177 .

Diano, Carlo. 1974 [1939-42]. Scritti Epicurei. Florence: Leo S. Olschki.

Erler, Michael and Malcolm Schofield. 1999. "Epicurean Ethics.” In Keimpe Algra, Jonathan Barnes, Jaap Mansfeld, and Malcolm Schofield, eds., The Cambridge History of Hellenistic Philosophy (Cambridge: Cambridge University Press), 642-74.

Geer, Russel M. 1964. Epicurus: Letters, Principal Doctrines, and Vatican Sayings. New York: BobbsMerrill.

Giannantoni, Gabriele. 1984. "Il piacere cinetico nell'etica epicurea." Elenchos 5: 25-44.

Gigante, Marcello. 1995. "Reading Philodemus' On the Good King according to Homer. In Marcello Gigante, Philodemus in Italy: The Books from Herculaneum, trans. Dirk (Ann Arbor: University of Michigan Press, 1995), pp. 63-78.

${ }^{34}$ It gets short, if any, shrift in Bok 2010; see especially her chapter on "Discordant Definitions" of happiness, pp. 35-58. 
Journal of Ancient Philosophy Vol. VI 2012 Issue 1

Gigante, Marcello and Tiziano Dorandi. 1980. “Anassarco e Epicuro Sul regno.” Siculorum Gymnasium 33: 479-497.

Giovacchini, Julie. 2008. Épicure. Paris: Les Belles Lettres.

Gosling, J.C.B. and C.C.W. Taylor. 1982. The Greeks on Pleasure. Oxford: Oxford University Press.

Held, Katharina. 2007. Hêdonê und Ataraxia bei Epikur. Paderhorn: Mentis Verlag.

Hossenfelder, Malte. 2006. Epikur. 3rd ed. Munich: Beck.

Inwood, Brad and L.P. Gerson. 1994. The Epicurus Reader. Indianapolis: Hackett Publishing.

Kline, A.S., trans. 2003-05. Horace. Available at http://www.poetryintranslation.com/PITBR/Latin/ HoraceEpistlesBkIEpIV.htm (accessed 12 October 2010).

Konstan, David. 2008. "A Life Worthy of the Gods": The Materialist Pyschology of Epicurus. Las Vegas: Parmenides Publishing.

Konstan, David. 2011. "A Pig Convicts Itself of Unreason: The Implicit Argument of Plutarch's Gryllus," in Nina Almazova, Olga Budaragina, Sofia Egorova, Denis Keyer, Dmitri Panchenko, Anatolij Ruban and Alexander Verlinsky, eds., Variante Loquella: Alexandro Gavrilov Septuagenario (Saint Petersburg: Bibliotheca Classica, 2011) = Hyperboreus 16-17 (2010-2011) 371-85.

Long, A. A. and D. N. Sedley. 1987. The Hellenistic Philosophers. 2 vols. Cambridge: Cambridge University Press.

Maso, Stefano. 2008. Capire e dissentire: Cicerone e la filosofia di Epicuro. Naples: Bibliopolis = Elenchos 48.

Mitsis, Phillip. 1988. "Epicurus on Death and the Duration of Life." Proceedings of the Boston Area Colloquium on Ancient Philosophy 4: 295-314.

Mitsis, Phillip. 1996. "Epicureans on Death and the Deprivations of Death." In Gabriele Giannantoni and Marcello Gigante, eds., Epicureismo Greco e romano: Atti del congress internazionale, Napoli, 1926 maggio 1993. Naples: Bibliopolis. 805-12.

Morel, Pierre-Marie. 2009. Épicure. Paris: Vrin.

Newmyer, Stephen T. 2006. Animals, Rights and Reason in Plutarch and Modern Ethics. London: Routledge.

Nikolsky, Boris. 2001. "Epicurus on Pleasure." Phronesis 46: 440-65.

Nussbaum, Martha C. 1994. The Therapy of Desire: Theory and Practice in Hellenistic Ethics. Princeton: Princeton University Press.

Nussbaum, Martha and Amartya Sen, eds. 1993. The Quality of Life. Oxford: Clarendon Press.

O’Keefe, Tim. 2010. Epicureanism. Durham: Acumen.

Prost, François. 2004. Les théories hellénistiques de la douleur. Louvain: Éditions Peeters = Bibliothèque d'Études Classiques 37. 
Journal of Ancient Philosophy Vol. VI 2012 Issue 1

Purinton, Jeffrey S. 1993. "Epicurus on the telos", Phronesis 38: 281-320.

Repici, Luciana. 2008. "Il pensiero dell'anima in Epicuro e Lucrezio." In Francesca Alesse, F. Aronadio, M.C. Dalfino, L. Simeoni, and Emidio Spinelli, eds., Anthropine Sophia: Studi di filologia e storiografi a filosofica in memoria di Gabriele Giannantoni (Naples: Bibliopolis), pp. 379-406.

Ramelli, Ilaria and David Konstan. 2010. "A Short History of Xapó: Hellenistic Moral Philosophy to the New Testament." Exemplaria Classica 14: 185-204.

Roskam, Geert. 2007a. "Live Unnoticed": $\Lambda \alpha ́ \theta \varepsilon \beta \iota \omega ́ \sigma \alpha s$. On the Vicissitudes of an Epicurean Doctrine. Leiden: Brill = Philosophia antiqua 111 .

Roskam, Geert. 2007b. A Commentary on Plutarch's De latenter vivendo. Leuven: Leuven University Press.

Rosenbaum, Stephen E. 1990. "Epicurus on Pleasure and the Complete Life." Monist 73: 21-41. Available online at http://wiki.gonzaga.edu/alfino/index.php/Epicurus_on_Pleasure_and_the_Complete Life (accessed 12 October 2010).

Salem, Jean. 1989. Tel un dieu parmi les hommes: L'éthique d'Épicure. Paris: J. Vrin.

Smith, Martin Ferguson, ed. 1993. Diogenes of Oenoanda: The Epicurean Inscription. Naples: Bibliopolis.

Sorabji, Richard. 1993. Animal Minds and Human Morals: The Origins of the Western Debate. Ithaca: Cornell University Press.

Striker, Gisela. 1988. "Commentary on Mitsis." Proceedings of the Boston Area Colloquium on Ancient Philosophy 4: 315-320.

Tsouna, Voula. 2007. The Ethics of Philodemus. Oxford: Oxford University Press.

Verde, Francesco, ed. and trans. 2010. Epistola a Erodoto. Introduction by Emidio Spinelli. Rome: Carocci Editore.

Warren, James. 2002. Epicurus and Democritean Ethics: An Archaeology of Ataraxia. Cambridge: Cambridge University Press.

Warren, James. 2009. "Aristotle on Speusippus on Eudoxus on Pleasure." Oxford Studies in Ancient Philosophy 36: 249-81.

Wheeler, M.R. 2003. "Epicurus on Friendship: The Emergence of Blessedness." In Dane R. Gordon and David B. Suits, eds., Epicurus: His Continuing Influence and Contemporary Relevance (Rochester: RIT Cary Graphics Arts Press, 2003), pp. 183-208.

Wolfsdorf, David. 2009. "Epicurus on Euphrosunê and Energeia (DL 10.136)." Apeiron 42: 221-57.

Woolf, Raphael. 2004. "What Kind of Hedonist Was Epicurus?” Phronesis 49: 303-322.

Woolf, Raphael. 2009. "Pleasure and Desire." In James Warren, ed., The Cambridge Companion to Epicureanism (Cambridge: Cambridge University Press), 158-78. 